Volume 46

Issue 3 Reflecting on the Legal Issues of Our

Times: New York Law School Faculty

Article 4

Presentation Day

January 2003

\title{
The Shape of the Universe: The Impact of Unpublished Opinions on the Process of Legal Research
}

William R. Mills

New York Law School

Follow this and additional works at: https://digitalcommons.nyls.edu/nyls_law_review

Part of the Courts Commons, Legal Education Commons, Legal Profession Commons, and the Legal Writing and Research Commons

\section{Recommended Citation}

William R. Mills, The Shape of the Universe: The Impact of Unpublished Opinions on the Process of Legal Research, 46 N.Y.L. ScH. L. REV. (2002-2003).

This Article is brought to you for free and open access by DigitalCommons@NYLS. It has been accepted for inclusion in NYLS Law Review by an authorized editor of DigitalCommons@NYLS. 


\title{
THE SHAPE OF THE UNIVERSE: THE IMPACT OF UNPUBLISHED OPINIONS ON THE PROCESS OF LEGAL RESEARCH
}

\author{
William R. Mills*
}

\section{INTRODUCTION}

The appellate judicial opinion sits at the very heart of our legal system. Lawyers use these opinions as building blocks for their legal arguments. Legal theorists parse and analyze them. Judges apply them in cases through the doctrine of stare decisis. Precedents established in appellate judicial opinions are thought to promote the stability, certainty, and predictability of law. ${ }^{1}$

Judicial opinions are also the dominant focus of our system of legal education. From the first week of law school, students are taught the importance of finding case law precedent to support their legal arguments. Most attorneys remember law school as an endless procession of case opinions that had to be read, deciphered, briefed, classified, appraised, compared, memorized, and recited in socratic dialogue.

Research skills instruction in law school is centered primarily on various case-finding techniques. This is due in part to the primacy of the judicial opinion as a focus of the law school curriculum. ${ }^{2}$ But it is due in even greater measure to the difficulties inherent in finding relevant cases, as compared to other types of legal authority. While the body of statutes and administrative rules is always increasing, it is doing so at a fairly steady rate. In contrast, the body of judicial opinions is

* Associate Librarian and Adjunct Professor, New York Law School. SUNY Stony Brook, B.S. 1971; Columbia, M.S.L.S. 1978; Fordham, J.D. 1982. Specialist in legal research and computer applications that support this research. Long relationship with American Association of Law Libraries and Law Library Association of Greater New York. The author wishes to thank Professor Michael Sinclair of New York Law School, who reviewed an early draft of this paper, offering helpful suggestions; and Paul Mastrangelo, Technical Services Coordinator at New York Law School Library, who rendered useful assistance.

1. Martha J. Dragich, Will the Federal Court of Appeals Perish if they Publish? Or Does the Declining Use of Opinions to Explain and Justify Judicial Decisions Pose a Greater Threat?, 44 Ам. U. L. Rev. 757, 777-781 (1995).

2. See generally Robert C. Berring, Collapse of the Structure of the Legal Research Universe: The Imperative of Digital Information, 69 WASH. L. REv. 9 (1994). 


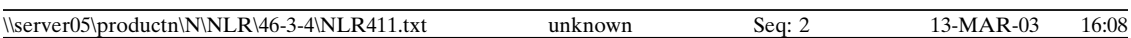

marked by nearly exponential growth that is unabated. ${ }^{3}$ In confronting legal issues that are complex or unsettled, it takes a skilled and fastidious researcher, using a diverse set of research tools, to ferret nuggets of relevant authority out of the vast mines of judicial precedent.

The researcher's burden might be eased to some degree if she were at liberty to ignore some portion of this authority, or if her work product were not held to a high standard of thoroughness. But the metes and bounds of her work are set, ultimately, by the doctrine of precedent. And the rules of professional responsibility insist that her research product reflect a thorough investigation of the entire universe of controlling judicial authority, no matter how large that universe might be. ${ }^{4}$ Even negative cases must be noted and distinguished, and controlling negative authority disclosed to opposing counsel. ${ }^{5}$ The bar is set high, as the law student is often reminded.

Another factor that adds to the case law researcher's burden is that odd phenomenon, the unpublished opinion. The very concept of the unpublished opinion embodies impediments to access. The law school curriculum devotes little attention to such opinions. Indeed, it is reasonable to speculate that many a law student gets all the way through without ever meeting one. No doubt this is because such opinions are consigned to an inferior echelon of legal authority. The federal court system hobbles the authority of unpublished opinions through court rules that prohibit, in varying degrees, their citation in legal briefs.

Yet unpublished opinions, and their attendant no-cite rules, sit at the center of a debate that is currently raging in the legal profession. This debate calls into question the very nature of our system of legal precedent. The debate invokes both the deepest historical foundations of the American legal system, and the most modern practices of American lawyers and judges. It stirs controversy over issues of government secrecy, and inequality among litigants before the bar of justice. A recent case, Anastasoff v. United States, 223 F.3d 898 ( $8^{\text {th }}$ Cir. 2000), va-

3. Christian F. Southwick, Unprecedented: The Eighth Circuit Repaves Antiquas Vias with a New Constitutional Doctrine, 21 Rev. Litig. 191, 198-199 (2002).

4. Lawrence D. MacLachlan, Gandy Dancers on the Web: How the Internet has Raised the Bar on Lawyers' Professional Responsibility to Research and Know the Law, 13 GEO. J. LEGAL ETHICs 607, 612-617 (2000).

5. ABA Model R. Prof. Conduct 3.3(a)3 (2000), cited in Stephen A. Fredley, Anastasoff v. United States: Nonprecedential Precedent, Judicial Power, and Due Process; a Case for Maintaining the Status Quo, 10 GEO. Mason L. Rev. 127 n.91 (2001). 


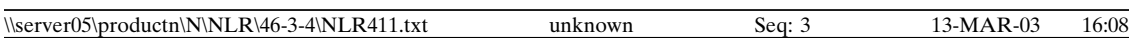

cated as moot 235 F.3d 1054 ( $8^{\text {th }}$ Cir. 2000), has reinvigorated this debate by giving it a new constitutional dimension, and placing it squarely within the context of judicial accountability and the appropriate separation of powers among our branches of government. This case has, in turn, become the subject of extensive analysis in subsequent cases and commentaries.

Much of the commentary on the Anastasoff case ignores, misunderstands, or gives short shrift to practical aspects of modern legal research, and to essential precepts of information policy. In this essay I will outline the recent history of the unpublished opinion, and summarize the current debate. I will then review the Anastasoff case, touch briefly on its progeny, and analyze the resulting implications for legal research. Finally, I will argue that while reform of the no-publish, nocite rules is imperative, such reform must be informed by deeper information policy considerations.

\section{BACKGROUND}

There may still be some lawyers who assume that federal appellate courts publish all their opinions, as this was still a valid assumption not so very long ago. ${ }^{6}$ The U.S. Supreme Court still authorizes for publication every opinion they hand down. But at the level of intermediate appellate courts, selective publication has become a well-established practice.

Commentators trace the origins of the practice to a 1964 report of the Judicial Conference, which formally recommended that only opinions with general precedential import be published at the circuit court level. ${ }^{7}$ Federal courts did not immediately embrace this recommendation, but by 1972 the Board of the Federal Judicial Center had proposed that all the circuits adopt plans to inhibit publication, and to prohibit citation of unpublished opinions. The Judicial Conference readily adopted this proposal, and by 1974 every circuit had a plan in place. Although a uniform rule was proposed, in the end the various circuits adopted plans and promulgated no-publication and no-citation rules to suit their own individual preferences. The circuits continue to administer their individual plans to this day. ${ }^{8}$

6. Kirt Shuldberg, Digital Influence: Technology and Unpublished Opinions in the Federal Courts of Appeals, 85 CALIf. L. REv. 541, 546 (1997).

7. Southwick, supra note 3, at 203.

8. Id. at 204. 


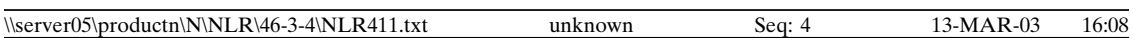

The rules restricting citation of unpublished opinions are intended as enforcement mechanisms for negating their precedential value. But different circuits' rules define these restrictions in different ways. Many allow citation to establish the law of the case, res judicata, or collateral estoppel. Others permit citation of unpublished opinions for persuasive effect, but deny them mandatory authority.

Detailed summaries of the intercircuit variations among these rules can be found in various sources, ${ }^{9}$ but far more interesting than these details are the statistics that show how the rules have been administered. Several empirical studies have detected substantial differences in publication rates among the circuits, leading their authors to conclude that judges do not make consistent publication decisions. ${ }^{10}$ The most dramatic figures, though, document the increasing rate of nonpublication, particularly in recent years. ${ }^{11}$ According to current statistics, nearly $80 \%$ of federal circuit court cases are now decided without a published opinion. ${ }^{12}$

Nearly every commentator who cites such figures, though, is quick to point out that vast numbers of what lawyers call "unpublished opinions" are not really unpublished at all. Indeed, many unpublished opinions are readily available through a variety of media to researchers who know where to look for them. Sly observers highlight the paradoxical nature of the "unpublished" designation, ${ }^{13}$ and deride its absurdity. ${ }^{14}$ In the common parlance of modern American lawyers, an "unpublished opinion" is an opinion that was never designated for publication

9. See, e.g., Jon A. Strongman, Unpublished Opinions, Precedent, and the Fifth Amendment: Why Denying Unpublished Opinions Precedential Value is Unconstitutional, 50 U. Kan. L. REv. 195, 198-201 (2001).

10. See generally Deborah J. Merritt \& James J. Brudney, Stalking Secret Law: What Predicts Publication in the United States Courts of Appeals, 54 VAND. L. REv. 71 (2001); see also Michael Hannon, A Closer Look at Unpublished Opinions in the United States Courts of Appeal, 3 J. App. Prac. \& Process 199 (2001); See also Robert A. Mead, 'Unpublished' Opinions as the Bulk of the Iceberg: Publication Patterns in the Eighth and Tenth Circuits of the United States Courts of Appeals, 93 Law Libr. J. 589 (2001).

11. See, e.g., Richard S. Arnold, Unpublished Opinions: A Comment, 1 J. Apr. Prac. \& Process 219, 221 (1999); Boyce F. Martin, Jr., In Defense of Unpublished Opinions, 60 Оніо Sт. L.J. 177, 188-189 (1999).

12. See Administrative Office of the United States Courts, Judicial Business of the United States Courts 44 tbl. S-3 (2000), quoted in Hart v. Massanari, 266 F.3d 1155, 1177 (9th Cir. 2001).

13. Charles E. Carpenter, Jr., The No-Citation Rule for Unpublished Opinions: Do the Ends of Expediency for Overloaded Appellate Courts Justify the Means of Secrecy?, 50 S.C. L. REv. 235, 249-250 (1998); See also Richard S. Arnold, The Future of the Federal Courts, 60 Mo. L. Rev. 533, 537 (1995). 


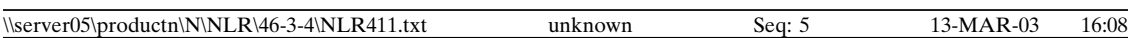

by the court that issued it, and never printed in any of the editions that comprise West's National Reporter System. (For federal circuit courts, this means Federal Reporter.) Thousands and thousands of such opinions are handed down every year.

It is easy to identify a variety of media in which such an opinion could have appeared, and thus have been, in some sense, "published." Most commentators make haste to recognize this, and to point to various sources in which these so-called unpublished opinions can be found. Quite predictably, the sources mentioned most often in this context are LEXIS and Westlaw. Other frequently cited electronic sources are CD-ROM's (a truly archaic form of cutting edge technology) and the Internet. Commentators further note the presence of unpublished opinions in legal journals and specialty reporters, ${ }^{15}$ thus acknowledging the fact that these opinions have been available to researchers since long before the dawn of the electronic information age.

Yet there can be no doubt that it was the advent of digital technology in the law, as manifested in case law databases and their attendant search engines, that fueled the current debate over unpublished opinions. ${ }^{16}$ With computers, lawyers are now closer than they've ever been to the possibility of searching the entire universe of appellate judicial opinions. Of course, in the decades that preceded the computer's arrival in the law library, lawyers were already sanguine in their conceit that they possessed the capability of searching this entire universe. The trick came down to defining the shape of the universe.

\section{The Debate}

Appellate courts' no-publication and no-citation rules have drawn ardent critics and supporters since their inception. ${ }^{17}$ The literature

14. Arthur B. Spitzer and Charles H. Wilson, The Mischief of the Unpublished Opinion, 21 Litig. 3, 4 (Summer 1995) (the release of unpublished opinions to Westlaw with the admonition "not for publication" has an "aura of comic naivete").

15. Strongman, supra note 9 , at 196 .

16. The litigation explosion, which brought about the circuits' no-publication and no-citation rules, happened almost concurrently with the arrival of the computer, in the mid-to-late 1970's. I will leave it to other commentators to speculate about this remarkable coincidence.

17. See, e.g., William L. Reynolds and William M. Richman, The Non-Precedential Precedent - Limited Publication and No-Citation Rules in the United States Courts of Appeals, 78 Colum. L. Rev. 1180 (1978); Lauren K. Robel, The Myth of the Disposable Opinion: Unpublished Opinions and Government Litigants in the United States Courts of Appeals, 87 


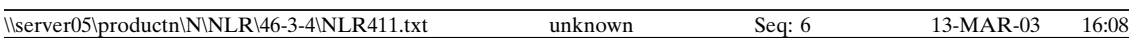

chronicling the debate is voluminous, and can be found in every sort of legal publication. Participants in the debate are drawn from a broad spectrum within the legal profession: academics, judges, practitioners of various specialties, and librarians. Members of all of these groups are well represented among the commentators, reflecting a broadbased concern.

Proponents of the no-publication and no-citation rules generally declaim their absolute necessity in averting the very paralysis of our judicial system. ${ }^{18}$ They point to the crisis of volume in modern litigation, which would so hinder the detailed and scrupulous review of precedent-worthy cases as to bring this process to a halt if judges were obliged to produce a full-fledged opinion every case. ${ }^{19}$

A complementary line of reasoning holds that courts generally designate their opinions as "not for publication" only in cases that are routine, straightforward, redundant, or otherwise unimportant. It is argued that a researcher could easily discover and apprehend the rationale for unpublished decisions through consultation of the body of published opinions. The publication of such trivial opinions would add nothing to the development of the law. Indeed, it would be bad policy to require publishers to publish, libraries to collect, and researchers to waste their time on opinions that merely belabor the obvious.

Critics of the prevailing system cite an array of abuses and inequities as flowing from the no-publication and no-citation rules. They argue that limited publication inevitably results in the creation of a shadow body of secret law. They deny the infallibility of judges in accurately predicting the precedential value of their opinions. Perhaps their most compelling arguments are based in the allegation that judges' and litigants' real-world behavior often betrays the notion that unpublished opinions are unimportant. The critics condemn the rules as providing the basis for a variety of dark judicial practices that extend

Mich. L. Rev. 940 (1989); Susan W. Brenner, Of Publication and Precedent: An Inquiry into the Ethnomethodology of Case Reporting in the American Legal System, 39 DePaul L. Rev. 461 (1990); Mark D. Hinderks and Steve A. Leben, Restoring the Common in the Law: A Proposal for the Elimination of Rules Prohibiting the Citation of Unpublished Decisions in Kansas and the Tenth Circuit, 31 Washburn L.J. 155 (1992); Robert J. Martineau, Restrictions on Publication and Citation of Judicial Opinions: A Reassessment, 28 U. Mich. J.L. Ref. 119 (1994); Carpenter, supra, note 14.

18. Thomas R. Lee and Lance S. Lenhof, The Anastasoff Case and the Judicial Power to 'Unpublish' Opinions, 77 Notre Dame L. Rev. 135,147-148 (2001).

19. See, e.g., Martin, supra note 11; Alex Kozinski and Stephen Reihnardt, Please Don't Cite This!, 20 Cal. Law. 43 (2000); Fredley, supra note 5. 


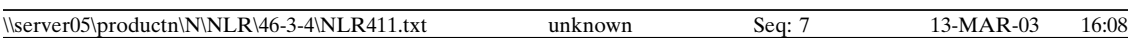

all the way from shoddy reasoning in unpublished opinions to horse trading in the determination of whether or not an opinion will be published. ${ }^{20}$ They foresee an inevitable diminution of judicial legitimacy and integrity.

One consideration that is often invoked in the current debate is the inequality of access to unpublished opinions. It is argued that rich litigants have better access to these opinions than do less affluent litigants. ${ }^{21}$ Frequent litigants have better access than "one shot" litigants. ${ }^{22}$ Litigants represented by specialists have better access than litigants represented by generalists. ${ }^{23}$ And, yet another aspect of inequality is the varying publication rates of opinions in different subject areas. Thus, for example, a lawyer researching an issue of securities law draws from a far richer body of published judicial authority than does a lawyer researching an immigration law question. ${ }^{24}$

Interestingly, one finds arguments invoking these inequalities of access in the commentaries of both detractors and supporters of limited publication. The detractors see the abatement of limited publication as a democratizing factor in judicial precedent, so long as it goes hand in hand with improved access to unpublished opinions through electronic databases. ${ }^{25}$ By this theory, publication of all immigration cases would open the entire universe of immigration law to all who needed research access to it. Supporters of limited publication see the nullification of no-citation rules as opening floodgates of judicial authority to the further detriment of litigants with limited resources. ${ }^{26}$ By this argument, publication of all immigration law cases would inevitably pose an insurmountable task for lawyers representing low-income immigrant clients.

In the final analysis, even the staunchest partisans on both sides of the debate acknowledge the legitimacy of arguments from the other side. Opponents of limited publication concede that the judiciary does in fact face a crisis of volume, ${ }^{27}$ and thus virtually none of these com-

20. See Shuldberg, supra note 6, at 551-553.

21. Fredley, supra note 5, at 154.

22. Robel, supra note 17.

23. Danny J. Boggs and Brian P. Brooks, Unpublished Opinions and the Nature of Precedent, 4 Green BAG 2D 17, 21-22 (2000).

24. Robel, supra note 17 , at 952-953.

25. Spitzer, supra note 14 , at 4 .

26. Daniel B. Levin, Anastasoff v. United States, 110 Yale L.J. 1295, 1298 (2001).

27. See, e.g., Joshua R. Mandell, Trees that Fall in the Forest: The Precedential Effect of Unpublished Opinions, 34 Loy. L.A. L. REv. 1255, 1261 (2001). 


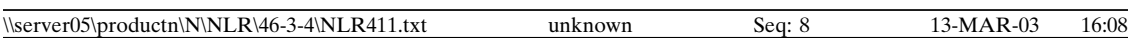

mentators has called for an outright abolition of the unpublished opinion. Supporters of limited publication tend to regard it as a necessary evil, ${ }^{28}$ and even judges who argue strongly against permissive citation of unpublished cases admit to consulting these very cases themselves, and even citing them occasionally in their own opinions. ${ }^{29}$ One commentator noted that the long line of arguments between the two sides had amounted to a stalemate, at least until recently. ${ }^{30}$

\section{Anastasoff}

In an essay he published in 1999, Richard S. Arnold, a highly regarded $^{31}$ Eighth Circuit judge, wrote that although he had authored many hundreds of unpublished opinions in his time on the bench, he had "always felt uneasy about it." 32 He described the system of limited publication as having a negative effect on psychology of judging by dint of the extraordinary discretion that it vests in judges. For example, a judge who feels that she should reach a certain result in a case, but who cannot justify that result under existing precedent, has the option of deciding the case in an unpublished opinion and thus sweeping the problem under the rug. In Arnold's view, a system that is open to this sort of abuse, in a world where judges are human beings, must be subject to question. ${ }^{33}$

Judge Arnold is rumored to have been waiting many years for the right sort of case through which to vindicate his sense of unease. ${ }^{34}$ His opportunity finally arrived with Anastasoff, a case that involved a routine tax dispute between the IRS and a retired teacher over $\$ 6,436$ in overpaid taxes. ${ }^{35}$ Writing for the Eighth Circuit panel, Arnold held

28. Jeffrey O. Cooper and Douglas A. Berman, Passive Virtues and Casual Vices in the Federal Courts of Appeals, 66 Brook. L. Rev. 685, 707-709 (2000).

29. Martin, supra note 11, at 196.

30. William J. Miller, Chipping Away at the Dam: The Future of Unpublished Opinions in the United States Courts of Appeals and Beyond., 50 Drake L. Rev. 181, 182-183 (2001).

31. See, e.g., Babbitt, 2 Judges Seen as Top Choices for Seat, Record (Northern New Jersey), May 11, 1994, at A20, available at 1994 WL 7766346. (Judge Arnold of Arkansas, a long-time friend of President Bill Clinton, had earlier been reported as being on the short list of candidates to replace Justice Harry A. Blackmun on the U.S. Supreme Court).

32. Arnold, supra note 11.

33. Id. at 223 .

34. John Borger and Chad Oldfather, The Uncertain Status of Unpublished Opinions, 57 Bench And Bar of Minn. 36 (Dec. 2000).

35. The issue that the parties thought they were arguing was whether Ms. Anastasoff's refund claim should be governed by the "Mailbox Rule," which deems certain 


\begin{tabular}{lllll}
\hline ||server05\productn|N|NLR\46-3-4|NLR411.txt & unknown & Seq: 10 & 13-MAR-03 & 16:08 \\
\hline
\end{tabular}

banc vacated the panel opinion for mootness. ${ }^{38}$ During this brief intervening time, the IRS had reversed its position, acquiesced in the rule that had been urged by the claimant's lawyers, and issued the taxpayer a full refund of her overpayment. Judge Arnold, writing again for the court, found that since there remained no tax refund dispute, there remained no case. He thus followed what he called "the appropriate and customary treatment" 39 of such a situation, which was to vacate his panel opinion.

In taking this step, however, Arnold sidestepped the issue of the binding authority of unpublished opinions, avoiding an absolute repudiation of the scheme of arguments that he had so meticulously advanced in his earlier opinion. Judge Arnold's parting shot in his en banc opinion was a declaration that the constitutionality of the Eighth Circuit's no-citation rule "remains an open question in this Circuit." 40

\section{In the WaKe of Anastasoff}

With Anastasoff's panel opinion vacated, its authority has entered a weird, twilight state. ${ }^{41}$ Significant contrary authority has since risen up. For example, Judge Kozinsky of the Ninth Circuit has authored an opinion ${ }^{42}$ that might aptly be called "the anti-Anastasoff," revisiting Arnold's historical ground, reaching opposite conclusions, and explicitly rejecting the Anastasoff analysis. Yet the force of Judge Arnold's arguments persists. Despite its vacated status, the panel opinion continues

38. Anastasoff v. U.S., 235 F.3d 1054 (8th Cir. 2000).

39. Id. at 1056 .

40. Id.

41. Although the panel opinion is retrievable on Westlaw, it appears under a red flag, and has been stripped of its West headnotes and key numbers. Nor have the opinion's original headnotes been compiled into any of West's key number digests. West explains that they maintain a very strong policy of stripping headnotes from vacated cases. "When an opinion is vacated or superseded, its law, and the headnotes representing that law, are nugatory. The theoretical underpinning for the very existence of a headnote is gone." E-mail correspondence from Daniel Dabney, Senior Director for Research and Development, West Group (Mar. 25, 2002) (on file with author).

However, consulting hard bound volume 223 of Federal Reporter, $3 d$ Series, one can still discover the original headnotes. One of these, which was assigned to the topic Courts, key number 107, states quite succinctly, "Unpublished opinions have precedential effect." Anastoff, 223 F.3d at 898.

42. Hart, 266 F.3d at 1155. See supra text accompanying note 12. 


\begin{tabular}{lllll}
\hline ||server05\productn|N|NLR\46-3-4|NLR411.txt & unknown & Seq: 11 & 13-MAR-03 & 16:08 \\
\hline
\end{tabular}

to be cited regularly in court cases, ${ }^{43}$ and commentators acknowledge its reverberating effects. ${ }^{44}$

While the authority of the Anastasoff panel opinion remains unsettled, Judge Arnold's reasoning carries significant implications for litigation practice, particularly when one considers the flood of judicial authority that would become binding on federal courts that accepted it. The most immediate and obvious effect of the opinion would have been to elevate all previous unpublished Eighth Circuit opinions to be the law of that circuit. The same result would obtain in every circuit that embraced Judge Arnold's arguments. And even in other circuits where Anastasoff had not been explicitly repudiated, advocates could ignore their local circuit rules and begin citing unpublished opinions, using Anastasoff's constitutional rationale as a justification. ${ }^{45}$ Observers generally agree that the issues involved are ultimately destined for Supreme Court review. ${ }^{46}$

Anastasoff and its progeny have unleashed a new flood of commentary on the limited publication debate in the literature of law. Many of these articles contemplate various practical implications that would flow from a general judicial acceptance of the argument that all unpublished opinions represent binding authority. A detailed assessment of this commentary is beyond the scope of this essay, except to the extent that the commentary involves implications for legal research. Although several commentators make reference to particular consequences for researchers, very little of the commentary fully recognizes the practical demands of ethical case law research in this context.

\section{IMPLiCATIONS FOR LegAL ReSEARCH}

As noted at the beginning of this essay, an ethical research undertaking in case law necessarily involves a thorough investigation of all authority relevant to the issues at hand. This universe of authority extends all the way back to the earliest judicial consideration of the points of law, no matter how distant in time that may be. Within this

43. Jerome I. Braun, Anastasoff v. United States: An Update, 85 Judicature 93 (2001) (A Key Cite search run on July 12, 2002 indicates that the Anastasoff panel opinion has been cited by courts 38 times since being vacated).

44. Braun, supra note 43, at 94; Miller, supra note 30, at 202-203.

45. Braun, supra note 43, at 93-94. This commentator views the Anastasoff panel opinion serving as a perennial last refuge for counsel advancing otherwise lost causes that an unpublished "precedent" might save.

46. See, e.g., Leane C. Medford, The Continuing Controversy over the Precedential Effect of Unpublished Opinions, 20 Aм. Bankr. InST. J. 26, 27 (Nov. 2001). 


\begin{tabular}{|c|c|c|c|}
\hline 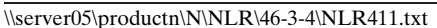 & unknown & Seq: 12 & 13-MAR-03 \\
\hline
\end{tabular}

research universe, unpublished opinions are not insignificant. ${ }^{47}$ Indeed such opinions, whether citable or uncitable, can prove quite important to the researcher, as empirical studies have amply documented. ${ }^{48}$ Furthermore, the constitutional arguments advanced by the Anastasoff panel would raise the significance of these opinions all the way up to the level of binding authority on the courts that decided them. The universe of relevant cases thus grows ever larger, and the researcher's burden ever greater.

Of course, the challenge of researching unpublished opinions is nothing new. Courts' limited publication regimes have never completely prevented researchers from finding unpublished opinions, any more than their no-cite rules have prevented lawyers and judges from using them. But, in the decades preceding the age of digital information, the unpublished opinion was a phenomenon of only minor significance within legal research. By the end of the $19^{\text {th }}$ century, the universe of published case law had become a well-defined and orderly system, embodied in the handsome editions that made up West Publishing Company's National Reporter System. West's case reporters set a standard that was universally accepted. Virtually all published legal writing, irrespective of publisher, was geared to the West cites. Opinions falling outside this system were not only disfavored by courts and judges, they were also, as a practical matter, by and large inaccessible to researchers. The legal profession, aided and abetted by West, kept tight control of the shape of the research universe. But, as soon as the computer entered the law library, the profession began to lose that control.

Many commentators in the current debate over limited publication see computers as something of a panacea for the problems facing modern legal researchers. These observers deprecate concerns over inequality and difficulty of access to case law with broad declarations that the anticipated development of electronic sources will soon render such issues a thing of the past. ${ }^{49}$ Few stop to consider the actual state of this development. ${ }^{50}$ Much of their commentary appears to proceed

47. See, e.g., Hinderks and Leben, supra note 17, at 213-214.

50. Commentators who do confront this issue foresee practical problems flowing from the Anastasoff panel's argument. See J. Wylie Donald and Pamela Keyl, Practicalities of Unpublished Opinions, N.J.L.J. 28, at col. 1 (Dec. 4, 2000); Levin, supra note 26, at 1301-1302; Sebrina Mason, Citing Unpublished Opinions: The Eighth Circuit Holds it Violates 


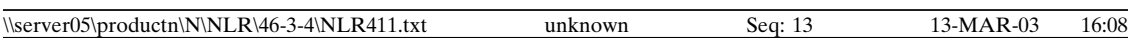

directly from the premise that large amounts of case law can be found on computers to the conclusion that effective case law research can be performed on computers in every circumstance. Such a conclusion is simply not supported by the realities of modern case law retrieval systems.

At its most superficial, this commentary makes the bare assertion that all (or nearly all) federal circuit court opinions, published and unpublished, are now being made available to the public for free through Internet Web sites. ${ }^{51}$ To the extent that it is accurate, this assertion may serve to counter the notion that there exists a body of secret law in the form of unpublished opinions that the judiciary is deliberately keeping hidden from public view. ${ }^{52}$ But the assertion alone is not enough to support the conclusion that the body of cases currently available for free on Internet Web sites comes anywhere near to being sufficient to sustain an adequate research effort in case law authority. These Web sites currently contain, at most, only those cases that have been loaded since their inception, which is rarely more than five or six years' worth of cases. Thus, only a small fraction of any circuit's cases, published or unpublished, can be retrieved through these sites. Not all of the free Web sites are hosted by the courts themselves, ${ }^{53}$ but even the sites hosted by courts lack an explicit commitment to the continuing maintenance of a permanent archive of opinions that would include all unpublished opinions. In the event that the computers serving a particular site became overburdened, there is no guarantee that some opinions might not be eliminated.

In addition to deficiencies in depth of coverage and questionable permanence, the free Internet also suffers from a fragmentation of sources. While each Web site provides search engines that offer various methods of retrieving cases, these retrieval systems differ from site to site, and there is no means of searching more than one at a time. Rather, the scrupulous researcher must first consult the "help" screen

the Constitution to Ignore the Precedential Value of Unpublished Opinions, 26 S. ILL. U. L.J. 119, 140-141 (2001).

51. See, e.g., Martin, supra note 11, at 185 ("All federal appeals court opinions, after all, are part of the public record. ... [The idea of an unpublished opinion] has become a fine, almost meaningless, distinction in a world of electronic research.")

52. See, e.g., Arnold, supra note 11, at 220.

53. Some of the circuit court sites are hosted by law schools. And, recent years' opinions from all circuits can also be found on www.findlaw.com, a site created as a private venture by a company that was recently acquired by West Group. On the state level, some sites are even hosted by law firms. 


\begin{tabular}{|c|c|c|c|}
\hline 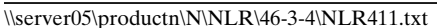 & unknown & Seq: 14 & 13-MAR-03 \\
\hline
\end{tabular}

for each site to learn its particular command syntax before attempting to construct a viable search. Even a small mistake in query formulation is likely to produce that are at best useless (because the search yields far too many hits or none at all,) and at worst misleading (because it omits significant ones.) Plus, given the limited scope of cases that can be found on these free Web sites, researchers generally have little incentive to gain proficiency in searching any single one.

A thorough research effort for case law in hard-copy sources has typically invoked a group of retrieval systems that afford different ways of accessing relevant cases. So long as there are redundant systems in place that offer different methods of retrieval, no single system needs to be perfect. For example, case digests, legal encyclopedias, and citators (such as Shepard's) all provide different methods for finding cases. No single system is perfect, but when used together they offer the researcher a good chance of finding all relevant legal authority on any issue. Here again, the free Internet is sorely lacking. ${ }^{54}$ Free Web sites that include collections of court opinions typically offer only a very limited and rudimentary set of retrieval mechanisms. These include the capability of searching by party name, date, judge, docket number, and key word. Natural language search engines are rare. Other methods are non-existent. And, once retrieved, the cases on the free sites are bereft of editorial enhancements such as headnotes and citator links that would lead the researcher to other relevant cases and facilitate case validation.

The task of researching case law on the free Internet is further complicated by the existence of numerous additional sources of unpublished opinions beyond the established court-supported sites. Many Web authors, from advocacy organizations, to law firms, to news providers to concerned citizens, routinely post court opinions on their sites. In doing so they are not constrained by any law or custom. Indeed, the current state of the Internet is such that any group or individual may, at minimal expense, post any number of unpublished court opinions to the Internet and thus "publish" them, in a sense that is no less formal than publication in the more established Web sources. These opinions are rightly seen as fugitive documents, since research-

54. One commentator notes that over-reliance on computer assisted legal research systems can lead to malpractice problems because such systems are of doubtful reliability in retrieving relevant cases on a particular issue. Duane A. Daiker, ComputerRelated Legal Malpractice: An Overview of the Practitioner's Potential Liability, 69 FLA. B.J. 12, 17-18 (1995). 


\begin{tabular}{|c|c|c|c|}
\hline 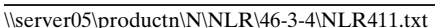 & unknown & Seq: 15 & 13-MAR-03 \\
\hline
\end{tabular}

ers have no reliable method for retrieving them. While the Internet has several excellent law-oriented index sites, such as Findlaw and Cornell's Legal Information Institute, none provide thorough, reliable access to the full body of case law thus posted.

There exist today only a handful of electronic resources that attempt to deliver the scope of coverage, the archival permanence, and the variety of retrieval methods that are essential to professional research in judicial authority. The obvious examples are LEXIS and Westlaw. ${ }^{55}$ Opponents of limited publication view these computer systems as the prevalent means by which future researchers will gain access to unpublished opinions in a world where federal circuit courts' no-publish and no-cite rules have been relaxed or abolished. ${ }^{56}$ Some of these critics acknowledge that LEXIS and Westlaw are expensive to use, and that thus they do not solve the problem of inferiority of access to unpublished opinions by less affluent litigants. ${ }^{57}$ Few of these observers recognize, though, that even the vast libraries of unpublished opinions currently found on LEXIS and Westlaw are incomplete and do not correspond to one another.

At their inception, neither LEXIS nor Westlaw was conceived of as a case reporter, in the ordinary sense of the term. ${ }^{58}$ Rather, these computer systems were viewed as retrieval tools, supplementing the existing digests and other index-based methods that lawyers had long used in finding published cases. It is reasonable to assume that the original databases assembled for LEXIS and Westlaw were comprised almost exclusively of cases that had been published in the print edi-

55. The only other examples worthy of mention are Loislaw and Versuslaw, which are both Web-based database services available through paid subscription. These are nascent business ventures marketed to lawyers as lower-cost alternatives to LEXIS and Westlaw. Neither comes close to competing with LEXIS or Westlaw in terms of coverage or features. As systems for pursuing case law research in an ethical way, their viability is (as Judge Arnold might say) an open question.

56. See Hinderks \& Leben, supra note 17, at 128-129; Shuldberg, supra note 6, at 558-561; Brenner, supra note 17, at 533-534; Strongman, supra note 9, at 222.

57. The advance of technology does not appear to be improving the accessibility of these services to the general public. A librarian from the Cuyahoga County Public Library recently reported that West Group signed, but then abruptly cancelled a flatrate, limited contract that would have allowed the library to offer Westlaw at its public terminals. This librarian concluded that West is no longer interested in providing this type of access. She further noted that LEXIS had shown no interest in such an arrangement either. Posting from Melissa Barr to law-lib discussion list (Apr. 11, 2002) (on file with author).

58. See Brenner, supra note 17 , at 508. 


\begin{tabular}{|c|c|c|c|}
\hline 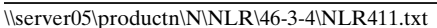 & unknown & Seq: 16 & 13-MAR-03 \\
\hline
\end{tabular}

tions of West's National Reporter System. But at an early stage in its development LEXIS began including unpublished opinions, and Westlaw soon followed suit. ${ }^{59}$ Indeed, the inclusion of unpublished opinions, not found on the other's system, emerged early as a factor in the competition between the two systems. However, the loading of unpublished opinions onto these systems was initially done on a selective basis, with each system adopting its own selection standards, and drawing from its own sources. ${ }^{60}$ The result is that neither system has compiled an exhaustive database of unpublished opinions from any federal circuit, much less any other jurisdiction or court. The sets of unpublished cases that a researcher encounters when searching the two systems are thus different from one another. ${ }^{61}$ And neither LEXIS nor Westlaw has ever undertaken a retrospective load of unpublished opinions from any court.

In 2001 West launched the Federal Appendix, a new case reporter devoted to circuit court opinions that had previously been referred to as "unpublished." Federal Appendix bears all the familiar trappings of other editions of the National Reporter System, including case synopses and headnotes authored by West editors, indexing in the key number digests, advance sheet supplementation, and cloth binding in beige with red and black spine labels adorned with gold leaf lettering. All Federal Appendix cases are full-text searchable on Westlaw, with editorial enhancements included. ${ }^{2}$ They have volume and page citations, equivalent to those of conventionally published cases. Each carries a disclaimer that it has not been selected for publication in Federal Reporter. West's stated policy is to publish in Federal Appendix every "unpublished" case that the various circuits send the publisher, omitting only those cases that are so purely formal as to not allow a synopsis and at least one headnote. ${ }^{63}$ At the same time, however, West cautions that some circuits-notably the Third, the Fifth, and the Eleventh-

59. Id. at 509-515.

60. J. Thomas Sullivan, Concluding Thoughts on the Practical and Collateral Consequences of Anastasoff, $3 \mathrm{~J}$. App. Prac. \& Process 425, 446 (2001).

61. It is ironic perhaps that the very case by which Judge Arnold felt bound in the Anastasoff panel, Christie v. U.S., 1992 U.S. App. LEXIS 38446 ( $8^{\text {th }}$ Cir. 1992), can be found on LEXIS but not on Westlaw.

62. This is in contrast to reported opinions that are subsequently vacated. See email correspondence from Daniel Dabney (on file with author), supra note 41 and accompanying text.

63. E-mail correspondence from Daniel Dabney (on file with author), supra note 41. 


\begin{tabular}{|c|c|c|c|}
\hline 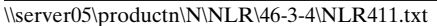 & unknown & Seq: 17 & 13-MAR-03 \\
\hline
\end{tabular}

have never released their unpublished cases to West or to anyone else. ${ }^{64}$

Thus it becomes clear that in recent years West has embraced an increasingly inclusive approach toward reporting unpublished opinions. It is fair to assume that Westlaw's principal competitor, LEXIS, is following a similar path. But while it is quite true that researchers now have access to many thousands of unpublished opinions through LEXIS and Westlaw, this should not obscure the fact that many thousands of other such opinions can not be found on either of these services. The ratio of opinions that can be found versus those that can not be found is unknown, ${ }^{65}$ and is in any case a moving target. What remains is the fact that, as repositories of federal circuit court cases, both LEXIS and Westlaw are patently incomplete.

\section{CONCLUSION}

The practice of limited publication of federal circuit court opinions is ripe for reform. A wealth of legal commentary enumerates the many negative aspects of this practice. Yet the outright nullification of circuit courts' no-cite rules combined with the elevation of all unpublished opinions to the rank of binding authority would result in an ethical research mandate that is very demanding. It is a mandate that modern case law retrieval systems cannot meet. To the extent that the panel opinion in Anastasoff can be seen as an attempt at reform, it represents a principled and intellectual approach that is ultimately unworkable from the researcher's point of view. One can only speculate as to whether his realization of this consequence may have been one reason why Judge Arnold was so quick to vacate his own opinion.

Other reform-minded commentators have called upon the courts to augment their free Web sites to include all of their unpublished opinions. ${ }^{66}$ The courts have yet to heed this call. These commentators appear not to have examined the previous track record of courts in

64. Id.

65. Hannon, supra note 10, includes a detailed analysis of statistics of unpublished cases that can be found on LEXIS and Westlaw for the various federal circuits. The author, at 208, notes that LEXIS and Westlaw show markedly different statistics in their coverage, both in regard to the number of unpublished opinions and the total number of opinions they contain. But the article sheds little direct light on the number of unpublished opinions that are not to be found on either service. Hannon, supra note 11, at 208.

66. See. e.g., Martin L. Haines, Publishing the Unpublished Opinion, 211 N.J. LAWYER 46, 49 (Oct. 2001); Sullivan, supra note 60, at 443-444.

R

R 


\begin{tabular}{|c|c|c|c|}
\hline 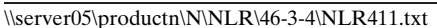 & unknown & Seq: 18 & 13-MAR-03 \\
\hline
\end{tabular}

creating case retrieval systems. But keen observers of the legal information marketplace recognize that the government has never performed well in the role of a legal publisher. ${ }^{67}$ It was, after all, the inefficient and disorganized state of government-led case reporting in the late $19^{\text {th }}$ century that resulted in the creation, and ultimate triumph, of West's National Reporter System, an undertaking founded entirely in private enterprise. As regards unpublished opinions, history points to the likely outcome that sources of these opinions will remain incomplete and fragmented until a sufficient market develops for them. ${ }^{68}$ When and if that time arrives, private enterprise will move to fully integrate them into the existing electronic research systems.

In the meantime, the legal profession should take notice that unpublished circuit court opinions have taken on a new significance in the process of legal research. These documents have become ever more accessible in both electronic and print sources. They can be easily cited using current citation forms. And the echo of constitutional authority from the Anastasoff panel opinion continues to resonate. All of these factors make it likely that courts will be under increasing pressure to recognize the value of unpublished opinions as precedent. At the same time, courts must eschew the hasty abandonment of no-cite rules, which would result in researchers being held to unattainably high standards in retrieving fugitive documents. The legal profession must work together with private enterprise, as it always has, to ensure that all significant authority is made accessible to researchers, and to educate professionals in modern research techniques.

67. See, e.g., Robert C. Berring, On Not Throwing Out the Baby: Planning the Future of Legal Information, 83 CALIF. L. Rev. 615 (1995).

68. The current situation can be likened to the state of publication of lower federal court cases in the mid- $19^{\text {th }}$ century. Between 1789 and the establishment of the Federal Reporter in 1880, some 233 different reporters had at various times printed these cases. But at the end of the century, the West Publishing Company painstakingly collected all of the cases that had been so variously published, and reprinted them in a new series called Federal Cases. This set is now used to the exclusion of the original reports. Miles O. Price \& Harry Bitner, Effective Legal Research 108-109 (Fred B. Rothman, 1969) (1953). 